\title{
Robert Mackay Fripp in the 1890s: peripatetic Pacific Rim architect
}

Michael Milojevic, School of Architecture \& Planning, University of Auckland

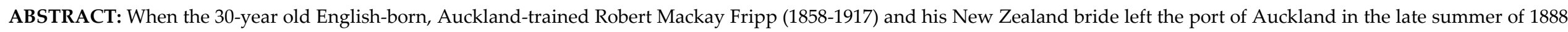

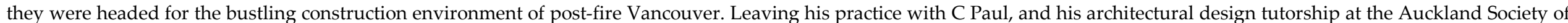

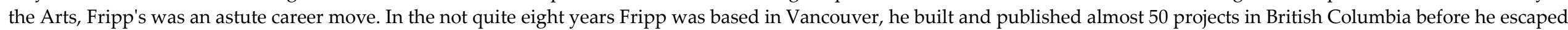

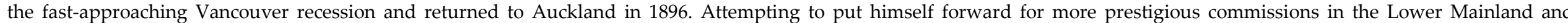

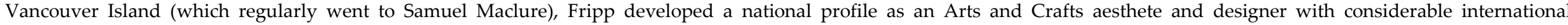

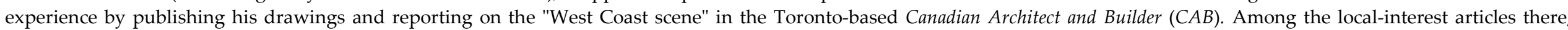

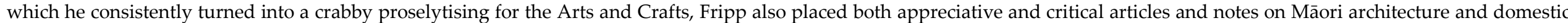

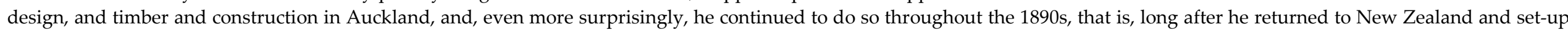

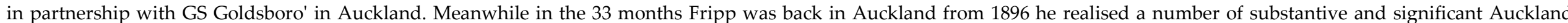

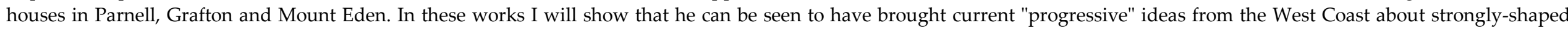

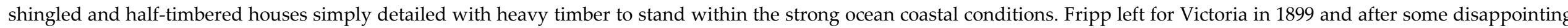

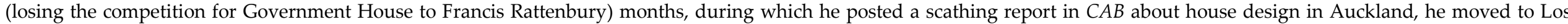

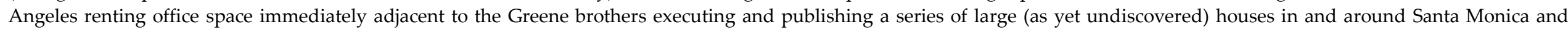
Pasadena throughout 1900-5.

Considering that English-born Canadian architect $^{1}$ Robert Mackay Fripp (1858-1917) ${ }^{2}$

${ }^{1}$ When, in 1995, Jeremy Ashford, then a graduate studen at the University of Auckland, working primarily on George Lloyd, outlined Fripp's significance to Auckland residential design in the late Victorian and early Modern period I had indeed never previously heard of Fripp; in his exhibition "Domestic Speculations" (Whangarei Art Museum/Te Wharetaonga o Whangarei, New Zealand: 20 June-30 July 2000), which focused on Fripp, Goldsbro and Jones, Ashford drew together much entirely new material for our understanding of Auckland residential design in the period 1880-1910 including the only known (to me at least, then and still) original drawing by Fripp. Since 1998 I have looked into "North American Fripp" when time and occasion have permitted and the following scholars have helped me piece together Fripp's North American career: Edward Mills, the first person to draw together Fripp material in an unpublished Parks Canada manuscript series report in 1976 and the author of the only published, if brief, biographical article on Fripp's British Columbia years; Donald Luxton (Vancouver) with whom I have shared much new material; Robert Hill of Kuwabara Payne McKenna Blomberg (Toronto) author of the as yet unpublished Biographical Dictionary of Canadian Architects 1700-2000 who started me off on many Fripp-associated subjects; John Ripley (Los Angeles) who didn't know what to make of his little stash of Fripp information until a librarian at Pasadena Public Library connected us up; Edward Bosley (Pasadena) with whom I established Fripp's connection with Greene and Greene; Jim Wolf (Burnaby) with whom I've made a number of site visits to putative Fripp houses. Without the help of research librarians and archivists, too numerous to detail here, at the central public libraries of Auckland, Birkenhead, Los Angeles, Pasadena and Santa Monica, Toronto, Vancouver, Vernon and Victoria, the City of Auckland Archive, City of Vancouver Archives, New Zealand Historic Places Trust [Auckland], City of Victoria Archives, Santa Monica Historical Museum, Scottish Records Office (Edinburgh), and the libraries of the Royal Institute of British Architects (London), Auckland War Memorial Museum, The Drawings and Archives Department of the Avery Architectural Library (New York), Canadian Centre for Architecture (Montreal), Huntingdon Library and Art Collection (San Marino), the State Library of Victoria (Melbourne) and the universities of Auckland, British Columbia, California at Los Angeles, Toronto, and Victoria, I would not have made the 
practiced in New Zealand for only 30 months $^{3}$ in the last decade of the nineteenth century the keywords "Fripp," "1890s" and "New Zealand" hardly seem to be a promising

headway on Fripp which I have. I also wish to thank Gordon Fulton (Ottawa), the late Jayne Kistner (Sierra Madre), Miles Lewis (Melbourne), Ann Scheid (Los Angeles) and John Stacpoole (Auckland) with whom I have corresponded on the subject of specific Fripp projects for their insights into practices contemporary with Fripp's

For Fripp's prominent role in Canada see Mills and Sommer, Vancouver Architecture passim; Fripp's Canadian credentials were sealed by his instigating the foundation of, and acting as the founding president of, the British Columbia Institute of Architects in 1909, comprising breakaway group of ten practitioners who formed what is now known as the Architectural Institute of British Columbia.

2 Fripp's biography may be collated from: Parker Who's Who 1913 p 186; Scholefield, British Columbia and Clarke, Vancouver 3:291; "Robert Mackay Fripp," Vancouver Daily World 1891 p 22; "Robert Mackay Fripp," Who's Who 1911 p 179; "Robert Mackay Fripp," Who's Who 1913 p 261 "Robert Mackay Fripp," Vancouver Daily World (17 December 1917) s 2, p 1; "The Late R Mackay Fripp" p 33 Fripp does not make an appearance in Kalman's History of Canadian Architecture though he does in Luxton Building though, of course this excludes the 16 years Fripp spent in New Zealand and California. Choosing "Mackay" over "MacKay" I follow Felsted, Franklin and Pinfield Directory p 331.

${ }^{3}$ Reconstructed from Fripp's various business notices in Canadian Architect and Builder he arrived in April 1896 and left in October 1898 subject. But while Fripp appeared in Auckland in 1890s for only as long as it took the dramatic mid-decade downturn in the British Columbia economy ${ }^{4}$ to be re-started by the Yukon gold rush in the last four years of the century, ${ }^{5}$ his arrival in Auckland was in fact a return. Fripp's first arrival in New Zealand in 1881, via Australia, at the age of 23 and was a longer engagement than that in the 1890s; by the time he left for good he had worked in the North Island, mainly Auckland, for a slightly over ten years in total, what would be not quite a third of his working life, and longer than anywhere else by that time. In Auckland he established a reputation, based on a number of "modern open plan" houses in Parnell, Grafton, Epsom, Remuera and Mount Eden, as "one of the city's leading architects." 6

${ }^{4}$ Luxton Building the West pp 101-103, and "A Letter from Australia" Canadian Architect and Builder 1896 n.p., on the general economic depression greatly affecting the building industry there, see Freeland Architecture p 199.

${ }^{5}$ Vancouver's population doubled in the time Fripp was in Auckland as a result of the Yukon Klondike gold discovery on 16 August 1896. The first public disclosure of the extent of the mineral wealth in the Dawson City area in mid-1897 resulted in the rush of approximately 100,000 prospectors, throughout 1898, up the West Coast, see Berton Klondike passim.

6 "Obituary" p 32. In the Candidate's Separate Statement of his RIBA Fellowship Nomination he records that in Auckland in the 1880s "executed eighty-seven
He left New Zealand for the second time (and forever) in 1898 at the age of 41.

Fripp's re-appearance in Auckland in the 1890s gives us an insight into practicing architecture in the boom-and-bust Commonwealth cities of the Pacific Rim where one year Fripp was doing a wide variety of residential, commercial and industrial work for the Marquis of Queensbury, Lord Aberdeen (the future Governor-General of Canada), the British Columbia Land Development Office, Canadian Pacific Railway executives, the sugar baron BT Rodgers and Dr Powell, a prominent Victoria developer, ${ }^{7}$ and the next

commissions" including 40 domestic projects, three stables including one for 100 horses, a rowing shed, additions to five hotels (Eden Vine, Wharf, Pier, Ferry, Windsor Castle, Royal and Bridge), stores, warehouses, a block of stores and three churches as well as minor alterations to 25 other buildings, R.I.B.A. Nomination Papers.

7 Collating published designs, tender notices and city building record information it seems that Fripp, in the 18 months before he left for Auckland, had worked on 13 residential projects: see "R. Mackay Fripp" p 8, also Fripp "Residence erected at Swan Lake" pp 88-89. For the commercial and public buildings see for example: Fripp "Small Hotel" n.p., Fripp "Old Men's Refuge" p 142f. The Inns of Court are found in the Vancouver Buildings Register; Vancouver Heritage Inventory. For Lord Aberdeen 
year, indeed within months, be left entirely without work and crossing the Pacific in search of gainful employment. ${ }^{8}$ After the seven year absence from Auckland he instigated a new Auckland partnership with George Selwyn Goldsbro', 9 a former student, in which Fripp was reasonably active in practice and able to take up an executive role in the Auckland Society of Arts. Not only was Fripp intent on publishing his designs in the architectural press (in Canada) but he was in a position to make comparisons and judgments of the state of architecture in the two centres and chose to publish his opinions wherever and whenever he could..$^{10}$ It is a particularity

Fripp did a cannery in Vernon; see "Contracts Open" p 2. 8 "crossing the Pacific" metaphorically as Fripp appears to have travelled to Auckland via England which may well have been prompted by the fact that his father died that October.

${ }^{9}$ Listed erroneously (Fripp's 'F's look a lot like 'T's and so this is a common typographical error in Fripp material) as "Tripp and Goldsboro, 316-317 Victoria Arcade, Queen Street, Auckland" and "R. M. Fripp, Victoria Avenue, Remuera, Auckland" see Wise's New Zealand Post Office Directory 1898-1899 p 1762. Goldsbro' (GS Goldsborough was abbreviated as either Goldsboro' or Goldsbro') is listed as active from 1869-1925; his practice record remains unpublished. See "George Selwyn Goldsbro" v II, p 316. Materials pertaining to his career are held in the Sheppard Collection File.

${ }^{10}$ Up to c1900 Fripp, it has been estimated, published of Fripp in fact that we hear about an architect's aspirations and disappointments in the shifting circumstances of 1890s architects in Auckland and Vancouver. In fact with Fripp one does not focus solely on his buildings but finds a career split between a certain level of success in architectural practice along side a prominent itinerant architectural polemicist, educator, journalist and organizer.

Indeed all things considered, Fripp was a serious peripatetic: we know of a dozen residential addresses and more than 20 professional addresses in seven cities in three countries. ${ }^{11}$ His intercontinental travels, multiple immigrations and re-immigrations, as may be reconstructed, suggest that he

more of his own designs than any other Canadian architect. In addition to his contributions to Canadian Architect and Builder (collated in Johnston and Chenier Index), Canadian Contract Record and Engineering Record, The Contract Record, Construction, The Architect and Engineer of California, Western Architecture and Engineering, Construction, Western Canada Contractor, and Builder and Contractor, Fripp published in local newspapers (see "Library and Archives Canada" n.p.) in Vancouver, Victoria and Vernon.

11 That is confirmed addresses from 1884 on and not including those instances for when we have a new practice address (ie in a different city) but no residential address for this location. constructed an "international" reputation ${ }^{12}$ relying, to some extent, on successive, often

${ }^{12}$ An example of Fripp engaging in self-aggrandizement, indeed constructing his own reputation in conjunction with contemporary misattributions, based, one presumes, on the "convenient" fact that there were two Alfred Smith architects one in Melbourne and another in Auckland. In his Candidate's Separate Statement of his RIBA Fellowship Nomination he states that he worked for, then with, and finally succeeding to the Smith practice (R.I.B.A. Nomination Papers). But this cannot be so. The Melbourne Smith, who designed the most admired Auckland building in its time, the Victoria Arcade, (published in "Victoria Arcade" completed 1885). as well as the New Zealand Insurance Company Building, had emigrated to Melbourne from London in 1851, having just completed The Army and Navy Club, Pall Mall, which is how Fripp identifies Smith. Smith was, in Fripp's time in Antipodes in the 1880s, the architect for a number of prominent bank and insurance buildings and houses in Australia. While there was indeed an "Alfred Smith, architect" in Auckland, he was a minor figure who had previously appeared in the Canterbury chapter, and while there is no corroborating evidence for a partnership with Fripp, a Smith and Fripp partnership is conceivable; indeed Fripp practiced at the same address but, as far as we know, with six other sole architectural practitioners. A Fripp-Smith connection is a possibility if, when Fripp apparently (though we have no corroborating evidence for this) worked in Australia, he had worked for Smith, in the practice of Alfred Smith and Arthur Ebden Johnson, as the prominent Johnson, was like Fripp, an exHorace Jones employee from the time of Fripp's stated tenure there. If Fripp emigrated to New Zealand in some connection with this work (for which evidence has not 
less than entirely productive, dislocations. In all one can estimate that he was involved in 160 projects $^{13}$ and practiced for over twenty years (in three stints) ${ }^{14}$ in Vancouver, five years in Los Angeles, ${ }^{15}$ about three years [in all] "in transit" between these places usually via London, and two each in Melbourne ${ }^{16}$ and Victoria. ${ }^{17}$ His "peripateticism," while chiefly

come to light) there is a possibility that it might have had something to do with these projects.

${ }^{13}$ This figure is ascertained as a simple compilation of all the data for confirmed built work from photographs and building permit records, all published designs (including furniture but not works of art), and notices of projects being given out to tender or simply undertaken (sometimes known only as ie. "seven houses" etc).

14 1888-1896, 1899-1901 and 1907-1917.

${ }^{15}$ Fripp was in the Los Angeles region from late 1901 or early 1902 to 1905; he had for a time an office in the centre of the city and later in Santa Monica; he claims in his own account of this period to have worked in Pasadena but there is nothing to corroborate this claim which was likely his way to stress his link with the Arroyo Secco architects Greene and Greene and others. 16 1880/1-1882

17 Fripp's residence in Victoria 1898-1899, published announcement of this and confirmed by his signed and dated published designs. However, considering that he actively sought larger government commissions, it seems that from time to time he was also resident in Victoria to make his presence, interest and abilities known. As Fripp's son, confirmed as born Robert Fripp in Vancouver, was born on 16 May 1889, that is presumably the terminus pro quem. driven by economic necessity and opportunism, can also be seen as the wanderlust of an architect and public figure seeking immediate experiences in a variety of practice and cultural environments. Indeed he practiced alongside and shared clients with critically-acclaimed practices such as the Greene brothers in Los Angeles and Pasadena, ${ }^{18}$ Francis Rattenbury in Victoria, ${ }^{19}$

18 The link between Fripp and the Greenes is based on the fact that they both worked from premises in the Grant Building (355 S Broadway, Los Angeles) in 1903 and that they shared an ex-patriot Canadian clients Margaret BS Clapham Spinks and the retired Judge William Ward Spinks for whom Fripp built a large house on Swan Lake, Vernon, British Columbia in 189495 and the Greenes built Spinks a house at 1344 Hillcrest Avenue, Pasadena in 1909. Between these projects, in 1903-4, the Greenes did one of their projects outside southern California for the Irish-Canadian immigrant barrister J Henry C Green, mystifyingly a throwback retardaire Queen Anne design, on Robson Street Vancouver. The Greenes, I have it on good authority, did not visit the site nor have the work supervised (Bosely, Pers. Comm., 2000); one wonders if Fripp, whose name was synonymous with the Arts and Crafts scene in Vancouver, was involved somehow. The drawings of the Greene's Green House are held in the Drawings and Archives Dept., Avery Library, New York.

19 Barrett and Liscombe Francis Rattenbury passim. Ten years younger than Fripp and arriving in British Columbia a decade after Fripp Rattenbury won the international competition to design the legislative
Samuel Maclure in Vancouver, ${ }^{20}$ and Eden Smith in Toronto, ${ }^{21}$ all leading Arts and Crafts

buildings in Victoria within months setting up on the West Coast. Subsequently as chief architect for the Canadian Pacific Railways Rattenbury designed several large hotels in the Rockies, Vancouver, and Victoria. Typically Fripp came second to Rattenbury in competition for the large commissions which in all eluded Fripp.

${ }^{20}$ Segger The Buildings of Samuel Maclure passim. Though Maclure was based for most of his career outside Vancouver he competed successful with Fripp for the city's wealthiest clientele and certainly partially because he was based in the capitals (first New Westminster then Victoria) the quality and quantity of Maclure's output was the more consistent. In 1902, for example, BT Rogers (see Kluckner M.I. Rogers p 27) for whom Fripp had done a house in 1890 in the West End, went to Maclure for his next (the second of three commissions) Vancouver house. Following Fripp's return from New Zealand in 1898 his design inclinations (witnessed by his Los Angeles houses (see Fripp "Types of Pacific Coast Houses" pp 47-61), likely the basis of his Vancouver Institute lecture "The Evolution of the House" delivered two months before he died: see "Vancouver Institute Lectures" n.p.), seem to mirror Maclure's more and more, as we might see this in Maclure's houses on Foul Bay Road, Pemberton Road, Rockland Avenue and Charles Avenue, all in Victoria, between the turn of the century and the outbreak of war. Rattenbury and Maclure beat Fripp in the competition (see "Competitive Design" plate following p ii) to for the design of the Lieutenant Governor's residence, Cary Castle in Victoria. An indication of Maclure's early prodigious output can be gained by noting that in his partnerships with Clow and then Sharp in New 
architects. Fripp's practice legacy is matched, one might even say eclipsed, by his role in the promotion of art and architectural education, especially drawing; later he became the Canadian apologist for the Arts and Crafts 22 and later still "professionalization." Leading the way with the critical appraisal of architecture he regularly submitted his designs for public scrutiny, mostly in the Canadian Architect and Builder as well as authoring a series of "Letters from British Columbia"23 in which he comments on the

Westminister he records 46 projects for the period January 1890-November 1892.

${ }^{21}$ Brown Eden Smith passim and Neal Eden Smith passim. Smith and Fripp, almost exact contemporaries, were, in the respective parts of Canada, leading apologists for Arts and Crafts ideals. Smith regularly invited Fripp to be part of the Architectural Eighteen Club activities either for the annual exhibition and when he was passing through Toronto on his way to Britain.

${ }^{22}$ Fripp's timing in establishing an Arts and Crafts Society in Vancouver in 1900 was au courant: the Boston Society of Arts and Crafts was founded in June 1897; the Chicago Society of Arts and Crafts in October of the same year; the Gustave Stickley Company, Syracuse/Eastwood New York was founded in May 1898; the Guild of Arts and Crafts New York in January 1900.

23 Fripp authored several anonymous "Letters from British Columbia"; [Fripp] "British Columbia Letter No. I" pp 50-51; [Fripp] "British Columbia Letter No. II" pp 137138; [Fripp] "British Columbia Letter No. III" pp 57-58; [Fripp] "British Columbia Letter No. IV" pp 234-236 state of the arts and the business of architecture and construction in the province; in all he submitted 43 designs, notes, columns, articles and brief project announcements to five journals. ${ }^{24}$ While one sees self-promotion on one level (regularly advertising his overseas experience as contributing to the quality of his present work), public roles engaged with the education of public sensibilities were a Fripp thing, (his grandfather and father were, respectively, founder and secretary of the Royal Watercolour Society). ${ }^{25}$ As it appears that no

[Fripp] "British Columbia Letter No. V" p 80; [Fripp] "British Columbia Letter No. VII" p 175.

${ }^{24}$ Fripp's interest in having his work seen and his views heard was particularly intense some years and so, for example in 1895 , he had a design or note published in almost every issue of $C A B$ and, to reinforce his authorship, he undertook to ensure his drawings were published in his trademark sepia tone; on the other hand, his "Letters" articles were unsigned. It is possible to see in some of his comments veiled critique of his competition in Vancouver: ie. when he complains that "there is a tendency to utilize the rough-cast and half timber effect without restraint and without breadth, a tendency with at times degenerates into positive meaninglessness" he is almost certainly taking aim at the sumptuous neo-Tudor designs of Samuel Maclure in Shaughnessy.

${ }^{25}$ Fripp was descended from the prominently creative Bristol Fripp-Pocock lineage; his grandfather Nicolas Pocock (1741-1821), predominantly a maritime artist was more than ten of his realized projects are extant $^{27}$ the evidence for Fripp is now largely textual. ${ }^{26}$

In surveying the situation of the Canadian building industry in 1895, Canadian Architect

founder of the Old Watercolour Society (London) and his great uncle Isaac Pococke a portraitist studies under Romney. Both have works held in national collections in Britain. Fripp's father George Arthur Fripp, primarily a watercolourist, exhibited (from 1844 on) scores of items at the Royal Academy and was honorary secretary of the (re-named) Royal Watercolour Society. Fripp's younger brother Thomas William Fripp was a founding president of the British Columbia Society of Fine Arts (1909-16) and president later again (1926-31) as well as president of the Vancouver Sketch Club (1920-21), a founding member of the British Columbia Art League. See Thompson "George A. Fripp" pp 25-26.

${ }^{26}$ In Vancouver: the Boulder Hotel (1890) in Gastown; the SB Snyder house (1910) at Kitsilano Point, the A Laidlaw house (1911) and "Oakhurst" Charles Gardner Johnson residence in Kerrisdale (1912), the FW Morgan (1912) and George Walkem (1913) houses in Shaughnessy, the Grace Court Apartments in the West End (1912) are extant in some form or other. In Burnaby the outbuildings for "Fairacres," the Henry $\mathrm{T}$ and Grace Ceperley mansion (1911), and the Henry Ramsay bungalow (1912) are extant, as is, in Vernon, the Spinks house, all in much altered conditions. None of Fripp's projects in the Los Angeles or Victoria area have been found. In Auckland the last remaining known Fripp project was demolished in 1999. See Kalman, Philips and Ward, Exploring Vancouver pp 30-31; Ward "Architecture" p D7. 
and Builder noted that while work for architects was "still generally ticking over" in Toronto and Montreal it had been "an exceedingly dull year in British Columbia" with "a great scarcity in employment" and "trade much depressed."27 As "a man of diverse interests and strong convictions, particularly with regard to the social importance of art and architecture," 28 Fripp indeed had other endeavours dear to his heart besides practice and took this opportunity to deliver "a course on art and archaeology" and "architectural ornament," and to accept an invitation to jury an annual exhibition competition in Toronto for Eden Smith's Arts and Crafts circle (soon be incorporated as The Eighteen Club). ${ }^{29}$ Fripp also took the time to publish, in Canadian Architect and Builder, five of his recent Vancouver projects: the Captain R. Archibald House, the Masonic Temple, a commercial block at Cordova and Hastings, and "a proposed business premises," as well as houses on the Coldstream Estate near Vernon. ${ }^{30}$ That spring in Canadian Architect and

27 "Building in Canada in 1895: Vancouver, B.C." p 12.

${ }^{28}$ Mills "Robert Mackay Fripp"; Luxton Building p 158.

${ }^{29}$ Fripp is also known to have been in Toronto in 1901 and 1902 on the invitation of the Architectural Eighteen Club.

30 see: Fripp "Residence at Vancouver" pp 42-43; Fripp
Builder Fripp published drawings for a "Book Case \& Writing Table in Smoking Room, made in Rimu, Mottled Kauri, Rewa Rewa \& Mangeo, New Zealand Woods for Cuyler A. Halland Esq. Design."31 The fact that his "Sketch for a Bungalow to be built of timber on a foundation of rubble rock walling. R.M. Fripp. F.R.I.B.A. Architect. August, 1895," was actually published, again in $C A B$, but in May 1900, shortly after Fripp returned to the West Coast, suggests that by mid-1895 it was public knowledge that Fripp had decided to reemigrate to New Zealand. ${ }^{32}$ Thomas Hooper, Francis Rattenbury and TC Sorby had already crossed the Straits of Georgia to set up shop in the provincial capital Victoria; of the 12 architects based in Vancouver in 1893 only seven remained by early $1898 .{ }^{33}$ Indeed the economic situation in the lower mainland deteriorated so unexpectedly rapidly, in late 1894, that it appears Fripp decided to leave Vancouver in the short time between his

"Foreman and Workman's House" pp 88-89; Fripp "Masonic Temple" pp 88-89; Fripp "Proposed Business Premises" pp 144-145; Fripp "Block erected" pp 24-25. ${ }^{31}$ see: Fripp "Book Case \& Writing Table" pp 56-57.

${ }^{32}$ see: Fripp "Sketch for a Bungalow" pp 96-97.

33 This comparison is based on the 1893 edition of Williams Official British Columbia Directory through to the 1897 edition of Henderson's British Columbia Gazetteer and Directory. public announcement to open a Vernon office appeared and the planned opening date. ${ }^{34} \mathrm{His}$ decision to return to Auckland, where he could pick up where he left off with his former business partners, colleagues, students, friends, mirrors, in a way, his opportunistic move in setting out for Vancouver in the first place, as his older brother Charles had settled in that city there shortly before he did and soon after his younger brother Thomas followed suit. ${ }^{35}$

${ }^{34}$ Unconfirmed reference to a notice in the Vernon News from Mills "Robert Mackay Fripp" in Luxton Building p 160.

35 Arriving in Vancouver in early 1888 Charles set up business together with Robert in April 1888 as "Robert MacKay Fripp and Charles Edwin Fripp, Architects;" their last published announcement of joint business activity appeared in "Filling the Blanks: Vancouver is Progressive" p 1, for a two storey frame store at Drake and Howe. Robert and Charles' brother Thomas arrived five years later in 1893 and indeed both of Robert's brothers became significant artists on the West Coast. It should, for the record, be noted that Robert and Charles were not in fact the first Fripps to practice architecture in Canada. Their uncle Sidney Bowles Fripp (Bristol, Gloucester 1823-Ottawa 16 Mar 1870) was an architect ("Fripp and Pocock Families of Bristol" n.p.). Note also that another uncle, Samuel Charles Fripp, was a prominent Bristol architect of the Bristol and Exeter Railway Company Office, Temples Meads and exhibited architectural drawings at the Royal Academy London in 
Even for a highly-mobile Victorian adventurer-architect who had travelled and worked in South Africa, the Subcontinent, Tasmania and Australia before arriving in New Zealand in 1881 and moving on to North America in 1888, New Zealand had a special place in Fripp's life and career. It was in Auckland that he had (by a very slight margin it must be admitted), to date, stayed put the longest and it had been his first significant practice period (1881-88), where he married (1887), and where the architects Philip Herapath and William Francis Hammond, who supported his (1890) RIBA accreditation application, ${ }^{36}$ practiced. The Minutes and Annual Exhibition catalogues of the Auckland Society of the Arts ${ }^{37}$ in the mid-1880s suggest

1838, 1839 and 1843. See esp. Crick Victorian Buildings $\mathrm{p}$ 43.

${ }^{36}$ While Fripp claims to have worked (he implies as an architect) in Adelaide, Sydney, and Melbourne, his proposers were the London architects $\mathrm{O}$ Hansard and JM Brydon (who having worked for Eden Nesfield and Richard Norman Shaw, and who himself been proposed by Alfred Waterhouse and JJ Stevenson, had significant Arts and Crafts credentials) and $P$ Herapath of Auckland (R.I.B.A. Nomination Papers); Fripp's RIBA membership was confirmed on 16 November 1891.

37 Here I'm following Ashford's discovery of Fripp's manuscript notes, as Society secretary, in the Minutes of the Auckland Society of Arts. that Fripp had been the first architect to promote architectural drawing in these art competitions, and that he was likely the city's, if not the country's, first architectural tutor. ${ }^{38}$ Indeed it is as a result of his public persona, and especially his strident aesthetic and architectural criticism, including articles about "New Zealand architecture"39 and "the arts of the Maori,"40 in the Canadian Architect and Builder, that, for someone with a only modest productivity, he cast a long shadow over the Auckland architectural scene.

When Fripp left for Auckland in 1895, where 19 architects advertised their practices, he was one of eight practicing architects in Vancouver. ${ }^{41}$ It appears that already in late 1894 or early 1895, before departing Vancouver for Auckland (via Toronto and London), Fripp pre-arranged a practice agreement with GS Goldsboro' such that,

${ }^{38}$ This important notes reads "Mr R Mackay Fripp - three pupils" which accords with his advertisement in Vancouver Daily Herald upon first arriving in Vancouver in March 1888 offering his services as an experienced architect and for "lessons and instructions in practical drawing and various branches of the building trade." Mills "Fripp" in Luxton Building the West p 158.

${ }^{39}$ Fripp "Architecture in New Zealand" p 169.

${ }^{40}$ Fripp "A Glimpse at Maori Art" pp 90-92.

${ }^{41}$ Wise's New Zealand Post Office Directory 1885-1886. within a few weeks of his arrival in New Zealand, Fripp and Goldsbro', located at 320 (later 316-317) Victoria Arcade, ${ }^{42}$ were awarded second premium in a competition for the Stock Exchange Building in Auckland and the first premium for the Taranaki Club in New Plymouth, neither of which were realized. However in their short-lived partnership they seem to have produced about a dozen projects, two or three public buildings and the rest residential projects in Parnell, Grafton, Mount Eden, Epsom, Remuera (where Fripp lived on Victoria Avenue) and Penrose.

The partnership's most prominent work was undoubtedly "Bloomfield," 9 Judge St. Parnell; the 1897-98 J Lucas Reid Bloomfield House sitting high over Judges Bay. This very substantial two-storey weather-boarded and shingled residence, a "Queen Anne style" composition, was approached by a southern corner porticoed entry. North-facing living rooms with a ground level corner verandah and an upper storey arched balcony took in the extensive views. ${ }^{43}$ Executed in

42 "George Selwyn Goldsbro" Encyclopaedia p 316.

${ }^{43}$ This is certainly the house for which Fripp made the claim in his article "Architecture in New Zealand" that he was required to do 24 sheets of drawings "to get what I 
weatherboard below and cedar shingle in the upper wall register, its roofline punctuated by substantial brick chimney breasts, the project comes across as a hybrid Queen Anne design. ${ }^{44}$ In Charles Bloomfield's panel the deep orange, dark browns and dark reds of the house, like the bell-casting, flush horizontal string courses and stubby colonnettes, highlights the progressive aesthetic compared with the white weatherboarded villa.

That same year the practice did "Rothesay," the big but largely unremarkably-planned Harold Heather Residence, Mount Eden; a plain form with a diagonally-angled bedroom wing, all sheathed in cedar shingles painted Indian Red with prominently unmoulded

wanted." As the original subdivision plans of the Point Resolution promontory on which "Bloomfield" was built were in fact WF Hammond's from the early 1880s, when Fripp was almost certainly in that office, this project as an especially strong connection with Fripp. The house faced the wide panorama of the Waitematā harbour; John Kinder's views of Campbell's Point and Hobson Bay to either side suggest the strongly Picturesque environment where Māori coastal traders used the beach below the house, now Dove Meyer Robinson Park, to stage their final approach to Auckland's commercial wharves.

${ }^{44}$ For the colonial version of the "tradition" in which Fripp was working see: Maitland Queen Anne Revival Style p 220. chimneys and in general devoid of machined fretwork. 45

For $\mathrm{T}$ Hope Lewis Esq MD, Fripp and Goldsbro' provided drawings for "Alterations and Additions to a House in Symonds Street Auckland" (signed and dated 7 August 1897, this is the only known original Fripp sheet) which proposed an altogether more spacious residence with larger and more generously lit main rooms with the doctor's surgery and ancillary service and storage rooms to the back of the ground floor. An exceptionally open stair landing includes a wide deep inglenook to the north and a wide archway opening to a large drawing room, with a new bedroom and bathroom to the back of the upper level, increasing the size of the two other bedrooms (if that's what they were previously), and generally opening the plan into a series of contiguous spaces. ${ }^{46}$ For Goldsbro's fiancé the practice completed a

${ }^{45}$ This description of "Rothesay" is based on the author's reading, in 2000, of the drawings "from a private collection," exhibited and summarised in Ashford "Domestic Speculations," and Ashford The Bungalow in New Zealand pp 12-13.

${ }^{46}$ This description of the Lewis House is based on the author's reading, in 2000, of the drawings "from a private collection," exhibited and summarised in Ashford "Domestic Speculations." sheet of $1 / 8^{\prime \prime}$ scale drawings (dated 29 November 1897) for a "Proposed Cottage at Epsom Auckland for Miss Meta Aicken" on Ngaire Street. This is a small shingled twostorey house with a Marseilles tile roof, three up and three down, and a porte cochere-like shed on the north side. The entry porch, with a deep and steep roof and stubby colonettes, is thrust forward to the street; a second floor balcony, opened by an arch over a dropped handrail-cum-cill, is incorporated into the volume of the house. The roofline is established by two brick chimneys, a steep shingled gable with a dropped finial and an occular window divided into nine panels by orthogonal mullion bars. Tall windows are "hung" from fascias marking the floor plates, the floors marked by bell-casting and a deep overhang on simple bracketing, the windows having Fripp's characteristic plate glass lower sash and six-Norman squares in the upper. ${ }^{47}$

47 This description of the Aitken cottage is based on the author's reading, in 2000, of the drawings "from a private collection," exhibited and summarised in Ashford "Domestic Speculations." Harry Ockenden's photograph of this house in the same exhibition shows that as built the windows were lowered in their walls such that they were disengaged from their visual conceit of being hung but instead "free-floating" string courses added to the wall face; the occular window was un-mullioned and gained a little drip mould on its top half, and the 
It is typical of the Fripp record that the "Proposed Cottage at Ellerslie, New Zealand. R.M. Fripp, F.R.I.B.A. and G.S. Goldsborough, Architects" 48 for the corner of Penrose and Jubilee Roads was published in Canadian Architect and Builder in January 1899. The project is for a modified side-centre plan with a distinctive contiguous organization of the main reception rooms: the dining room and drawing room, together with a deep fullwidth verandah off each communicating through extra-wide doors and large side light windows. A square-ish two-part entrance hall, the first part of which leads laterally to the main reception rooms with sliding doors between, and the second part gives to the kitchen and leading on to the bedrooms organized beyond, leads off the entrance porch with half-column corner supports, highly comparable to that on the Gladstone Road house, addressing the side yard rather than the streets on which the houses are

colonnettes normalised on the entry porch; the photograph appears to show the building has having unpainted shingles, those white sashes in dark architraves

${ }^{48}$ Fripp "Proposed Cottage" pp 10-11. One might ask if Fripp was perhaps communicating with Canadian Architect and Builder from New South Wales at this time. situated. In the low slightly-battered weatherboarded walls, the doors and windows are simply profiled in a way which stresses horizontality through small standard profile brackets to the six verandah posts and unusual six- or nine-lite upper sashes of all windows and door lites.

Fripp and Goldsbro's residential practice record was, otherwise, chiefly relatively modest houses, cottages and renovations and additions giving modest scope to innovative design potential. The drawings (dated 7 December 1896) for the WH Webbe House show a side-entry plan "transitional villa" with a modern asymmetrical plan arrangement in Grafton: a smaller drawing room next the front door vestibule and an interesting large corner-bayed cruciform music room. ${ }^{49}$ The house was to be weather-boarded with a shingled bay, and a (given the drawing was given a red-ish tone) Marseilles tile roof with three simple profiled brick chimneys. While a further three residential projects, for various reasons, can be attributed to the practice, and especially little is known about the Alfred

49 This description of the Webbe House is based on the author's reading, in 2000, of the drawings "from a private collection," exhibited and summarised in Ashford "Domestic Speculations."
Kidd Residence, and 80 Gladstone Road, Parnell.

We have less detail still for Fripp and Goldsbro's public and commercial work: nothing for the Stock Exchange Building project, or for a commercial building on Queen Street. Fripp's published Anglican church design ${ }^{50}$ is especially welcome in this

${ }^{50}$ Fripp "Sketch of an Anglican Church" pp 120-121; while "Auckland NZ" appears to have been added onto the drawing sheet in another pen, which might suggest that the design may not have originally been done for this specific location, the design seems to refer to Selwyn's timber churches; see Knight Selwyn Churches passim. In this design it appears that Fripp is calling for the qualities of a by-gone age in Auckland; he rails against churches "rushed up with an almost indecent haste on the lump sum contract principle," "wretched imitation heaped on wretched imitation," "amounting to an almost savage disregard for the beautiful" and concludes with a plea for "restraint," "a healthy regard for the appropriate utilization of materials and a stern refusal to countenance a cheap and flimsy mockery of detail... [employing rather] those simple lines and measures which confer dignity of purpose, and leave the rest for the future;" see Fripp, "The influence of the Modern Christian Church" pp 79-80. In some ways the plan form is an elaboration of the church for the Auckland Diocese Fripp had realized in 1886, St Paul's Flatbush (now Ōtāhuhu Parish, Manukau), with a baptistery at the western end position of the aisle and a porch on the north side mirrored by a vestry on the south; see NZHPT Building registration no. 690. 
regard. Clearly related to the Selwyn openstructure roof timber churches, the internalised structural tectonics, which seem indebted to Mountfort's 1886 St Mary's Church, Parnell, establishes a dramatically high roof structure marked by eight lanternlike dormers and a timber louvred tower and chevron-patterned copper-clad steeple as high as the plan is long. Fripp shows exposed trusses, tie beams and wind bracing with a richly varied and picturesque composition of roofs and gables over the chancel, transepts, vestry and vestibule and gable and gablette over the western end. The Thatcherite verticality is replaced by a banded tripartite horizontality of the wall: stonework base, halftimbering and a highly-glazed band of Norman squares and shingle.

Remaining a correspondent to the Canadian Architect and Builder, Fripp maintained his "presence" in Canada and the West Coast while quickly re-establishing, indeed enhancing, his public persona in Auckland. In 1896 he was elected onto the Board (he had been a "working member" in the 1880s and secretary to the Board for six months in 188283) of the Auckland Society of Arts from where he re-established the "architectural drawings," and then established a new "architectural photography," category and Auckland Institute of Architects prize in the "Miscellaneous" section of the Sixteenth Annual Exhibition. While Fripp and Goldsbro' were the only practice to exhibit in this category in 1896 and 1898 in the intervening year five others contributed architectural drawings. ${ }^{51}$ Fripp's early predilection for Arts and Crafts and Aestheticist integration of the fine arts, applied arts and architecture ${ }^{52}$ was,

${ }^{51}$ Fripp and Goldsbro' loaned architectural drawings and architectural photographs for the "Miscellaneous" section usually part of the exhibition in "Loan Collection Side Hall"; see Illustrated Catalogue 1884 n.p., in which Fripp is listed as having loaned three works including two of his father's works; Illustrated Catalogue 1887 in which Goldsboro' is listed as having won second prize for a drawing of a Corinthian capital. As Secretary of the Auckland Society of Arts from October 1882 to April 1883 Fripp's manuscript notes show indications of his strongly worded views: see Minutes of the Auckland Society of Arts.

52 Soon after leaving Belsize School, Fripp studied at the Reading School of Art where he recalls, in 1874-78, having done measured drawings and sketches of Shoreham and Steyning churches, parts of Salisbury and Saint Alban's Cathedrals, and Richard Norman Shaw's Greenham Lodge near Newbury while under construction in 1878-79 (while articled to James Swallow Dodd of Reading) and exposed through his architect and artist family to Arts and Crafts aesthetics and theories. To the first person in New Zealand to hire Fripp, the accomplished watercolourist, politician and in these years, combined with "tireless and unremitting efforts" in the way of organization and education which of course was characteristic of generations of Fripps by this time who also took on leadership roles. Indeed he would, upon returning to Vancouver in 1900, found the Vancouver Arts and Crafts Society, ${ }^{53}$ and be its first president and in a few years time, practicing in California would be president of the Los Angeles Arts and Crafts Association; 54 subsequently, upon again returning to Canada, and now taking up the cause of professionalization, Fripp led a splinter group of British Columbia architects in 1909 to

commissioner Sir William Fox, the name Fripp would certainly have been synonymous with representation in the fine arts: colour, light and space.

53 Meeting at the Vancouver Builders Exchange on 25 April 1900 Fripp was the first member of the provisional committee and founding president seeking "the greater encouragement of the arts and crafts... based upon similar lines to the now famous Arts and Crafts Society of London, founded by the late Mr. William Morris." "Arts and Crafts Association" p 93; note also Fripp's disappointment with the exhibitors and public at the Society's Summer Exhibition (see: Fripp "British Columbia Letter VII" p 175) as the only architectural drawings were his own, and there were as well oil paintings, watercolours and chalk drawings by his father George Fripp and brother Thomas Fripp.

${ }^{54}$ Anderson "Art and Artists" p V12. 
become the first president of the what he called the British Columbia Institute of Architects. ${ }^{55}$ Such involvements on top of his frequent relocations, for which Fripp seemed to have so much energy and optimism, likely substituted for, or perhaps more truthfully precluded, his ever leading a pre-eminent practice on a par with say Rattenbury or Maclure in British Columbia, or Hurst Seager and Mountford here.

Trumpeting his having weathered the economic slump of the last years in Western Canada, while gainfully employed in Auckland, Fripp announced, in the "Personals" column of the October 1898 Canadian Architect and Builder (perhaps it seems even while he was still in Auckland), his imminent relocation to the Board of Trade Building in Victoria, British Columbia. To that same edition he contributed "Architecture in New Zealand," a brief article reporting on his two and a half years in practice there in which, characteristically, he does not hold back on his disappointment with the state of practice and architecture in Auckland: "Such a state of affairs is hopeless, so much so that a man of some ability occasionally finds himself

${ }^{55}$ Luxton "Taming of the West" passim. in New Zealand, he almost invariably soon leaves in disgust." 56 Complaining of the total dominance of the Victorian villa in the New Zealand residential marketplace he inveighs against symmetricalized planning, low tin roof profiles, "the unremitting application of smooth stock claddings," and the trimming out of the shell in frilly mass-produced mouldings and turnings. Hampered by the lack of availability of good materials (he especially missed cedar shingles and clay roof tiles), ${ }^{57}$ properly experienced builders, the high construction costs "maintained by the rapacious building industry," and also the lack of his architect-colleagues' ingenuity, led Auckland houses to be "flimsy ugly mushrooms .... covered with mean little hip and valley roofs of galvanized iron." 58 He was very likely referring to his experience with the Lucas Reid Bloomfield House (Judges Bay, Parnell, 1897) when he claims that he needed to do "twenty-four sheets ... designing everything myself, and seeing it made too ... for what would, in British Columbia, be a

${ }^{56}$ Fripp "Architecture in New Zealand" p 169.

57 Salmond Old New Zealand Houses pp 122-123 (Marseilles tile), 202 and 204 (cedar shingle), but in both cases he dates the use far later than Fripp's introduction; see also Freeland Architecture in Australia pp 193-194. ${ }^{58}$ Fripp "Architecture in New Zealand" p 169.
$\$ 5000$ house." The equally strong pronouncements of the older Horbury Hunt in Sydney ${ }^{59}$ and the younger Gerald Jones in Auckland suggest that scathing critiques were the norm for leaders in Arts and Crafts sensibilities $^{60}$ but one senses that Fripp's peripatetic lifestyle may have left him in a state of permanent disaffection with the realities of architectural production and cities in New Zealand, Canada and America. ${ }^{6}$

59 The descriptors "outspoken criticism," "sermonizing," "perpetual president," "extreme prolixity" and "conceited" used to characterize the Canadian-born Hunt might also apply to Fripp: see Freeland Architect Extraordinary and Reynolds John Horbury Hunt passim.; also Herman The Architecture of Victorian Sydney p 145 in which Hunt's overbearing personality is made clear in the realm of architectural organizations and aesthetic criticism.

${ }^{60}$ In the section titled "Our Dreadful Architecture" Jones shows himself to be a younger malcontent from the William Morris stable (Jones "How Houses May Be Improved" p 1133; as noted in Shaw New Zealand Architecture p 87.

${ }^{61}$ For example on the architecture of Victoria in 1894 Fripp is scathing: "hoping to find something of virile western character ... is doomed to disappointment, for the buildings prove to almost wholely flat roofed, twostoried structures of feeble non-descript sort with a monotonous skyline of open parapets and crude cornices" [Fripp] "British Columbia Letter No. I" p 50; and upon returning to British Columbia in 1900 Fripp notes cultural sophistication "In New Zealand [where] we find every town whose inhabitants number a very few 
Fripp's published critique signaled to his Canadian readers that, aesthetically-speaking, Auckland, where he had cut his teeth as an architect in the previous decade, had in the interim become foreign territory for him. While in the 1880s Fripp brought sophisticated residential design standards, such as the wrap-around and corner verandah villa form from the Antipodes, ${ }^{62}$ in the late 1890s Fripp shunned the hideous colonial. Canadian Architect and Builder readers were meant to record that for an architect with international experience and strong aesthetic preferences Victoria and Vancouver were more sophisticated architectural and construction environments in which he was now ready (indeed relieved) to re-resume practice. Now what he found worthy ${ }^{63}$ to

thousands is fairly well provided with museums, art gallery, art schools, public library and town hall" [Fripp] "British Columbia Letter No. III" p 57. Also see Fripp's tirade against the local press's self-inflationary talk of Vancouver's "magnificent architecture" see: [Fripp] "British Columbia Letter No. VI." p 142.

62 For example: from Walter Robinson's late 1840s Government House for Sir George Grey on Karangahape Road, Auckland to the late 1880s AJ Dana House on Robson Street and 1890 BT Rogers House on Georgia, both in Vancouver

${ }^{63}$ Fripp "A Glimpse at Maori Art" pp 90-92; this is, I believe, the first article ever published in Canada on the subject of Māori work. communicate in the Canadian Architect and Builder was the authentic Māori in which construction and art were seen as one: an ideal Arts and Crafts scenario. ${ }^{62}$ In his 1900 "glimpse" of Māori building arts, comprising long captions to 16 photographs, Fripp contrasts "the picturesque richly-carved dignified meeting house" with the "vulgar little weatherboard church," noting the derisory quality of the colonists' machined timber stock over hand-worked Māori building components. Making cultural-social parallels and deriding "British civilization" in the process, Fripp's encomium, not unlike Frank Lloyd Wright's response to seeing the Hõ-õ-den, the Japanese pavilion, a half-scale replica of a traditional Meiji Japanese building showing furnishings, artifacts, implements and screens at the 1893 Columbia World Exposition, ${ }^{64}$ on the indigenous building

${ }^{64}$ Hitchcock In the Nature pp 26, 32, 34, 35, 59; Hitchcock "Frank Lloyd Wright" pp 46-63. Nute Frank Lloyd Wright passim. And see also Wright, who, in a 1908 article "In the Cause of Architecture," described the relationship of Japanese art to his "organic" design, explaining that for the Japanese, design was a spiritual endeavour, the highest form of achievement, and the mother of all the arts and crafts. (The Hō-ō-den was a half-size replica of a Fujiwara-era Japanese temple 1886 Edward Sylvester Morse (1838-1925) had published Japanese Homes and Their Surroundings, the first Western treatise on Japanese traditions of New Zealand, was fully aligned with his increasingly strident Arts and Crafts sensibilities. ${ }^{65}$ Fripp was only too pleased to declare: "it's not too much to say that the Maori as an architect was a much better artist than his white successors are."66

After a few months in Victoria though Fripp returned to Vancouver and re-set his sights again, this time on the affluent environment of Los Angeles, where, on average, the quality of bungalow design eclipsed what was achievable in British Columbia and in some avant garde practices, such as the Greene's, exotic traditions, where, merged with the "artistic" Californian house form into a distinctly new architectural quality, Fripp practiced for almost five years. If Fripp can be seen as the chief importer into Auckland of modern West Coast, even specifically Californian, sensibilities in house design ${ }^{67}$ this

residential architecture of the Meiji period (1615-1868)).

${ }^{65}$ Interestingly there is no evidence that he found critical parallels in the arts of the indigenous people of the West Coast.

${ }^{66}$ Fripp "A Glimpse at Maori Art" p 91.

${ }^{67}$ One might compare Fripp's NZ-US connection to the career of the Australian-based (since 1889) Englishtrained James Peddle who, also "attracted to the bungalow at mid career," emigrated to Southern California and set up practice in Pasadena in 1911 and 
was before, it seems, he ever set foot in California and from where, characteristically, he published a profusely illustrated survey of his work there, including some of his very most substantial projects, but this body of work, as yet remains unrediscovered.

like Fripp returned whence here came, in Peddle's case to Sydney, in January 1914. Peddle re-established practice with SG Thorpe, and as such his practice uniquely linked England, in Australia and America directly. In the Sydney area his houses blended English cottage and California bungalow forms: dark stained woods, halftimber gables, thrusting roof forms, deep verandahs, low roof pitches and brick piers: see Peddle, "Some Lessons" p 84 . 


\section{REFERENCES}

Anderson, Antony E "Art and Artists" Los Angeles Times (26 May 1907) V12.

"Arts and Crafts Association" Canadian Architect and Builder (May 1900) XIII(5):93.

Ashford, Jeremy The Bungalow in New Zealand. Auckland: Penguin Books New Zealand, 1994.

Ashford, Jeremy "Creating Architectural Histories"' Domestic Speculations. [exhibition pamphlet]. Auckland and Whangerei. 2000.

Ashford, Jeremy "Domestic Speculations", Circa [Te Wharetaonga o Whangarei Magazine] 12 [June-July 2000].

Auckland Society of Arts Sixteenth Annual Exhibition 1896 [catalogue] Auckland, 1886.

Auckland Society of Arts Seventeenth Annual Exhibition 1897 [catalogue] Auckland, 1887.

Auckland Society of Arts Eighteenth Annual Exhibition 1898 [catalogue] Auckland, 1888.

Barrett, Anthony and W. Liscombe W Rhodri. Francis Rattenbury and British Columbia Architecture and Challenge in the Imperial Age. Vancouver: University of British Columbia Press, 1983.

Berton, Pierre Klondike: The Last Great Gold Rush, 1896-1899. Toronto: McClelland and Stewart, 1972.

Bosely, Edward R. Personal Communication, Interview, at Gamble House Pasadena, 2000.

Brown, W Douglas Eden Smith: Toronto's Arts and Crafts Architect Toronto: [Privately published], 2003.

"Building in Canada in 1895: Vancouver, B.C." Canadian Architect and Builder (January 1896) IX(1):12.

"Competitive Design for Government House, Victoria, B.C.- Awarded Second Premium. R. M. Fripp. F.R.I.B.A. Architect" Canadian Architect and Builder (July 1901) XIV(7) plates following pp ii, iv.

"Contracts Open" Canadian Contract Record (26 November 1892) iii:2.

Crick, Clare Victorian Buildings in Bristol. Bristol: Redcliffe Press, 1978.

Felsted, Alison, Jonathan Franklin and Leslie Pinfield Directory of British Architects 1834-1900. London: Mansell, 1994.

"Filling the Blanks: Vancouver is Progressive" Vancouver Daily World (Saturday, 29 March 1890):1.

Freeland, John Maxwell Architect Extraordinary. The Life and Work of John Horbury Hunt: 1838-1904. Melbourne: Cassell Australia, 1970.

Freeland, John Maxwell Architecture in Australia. Melbourne: Cheshire, 1970.

"Fripp and Pocock Families of Bristol, UK" Family Tree, last updated 12 November http://web.ukonline.co.uk/bean95/ft/frippuk/pafg15.htm

Fripp, Robert Mackay "A Glimpse at Maori Art" Canadian Architect and Builder (May 1900) XIII(5):90-92; also the double page spread of "Specimens of Maori Art, Illustrating Article in this number by $\mathrm{Mr}$ R.M Fripp, F.R.I.B.A.'."

Fripp, Robert Mackay "Architecture in New Zealand" Canadian Architect and Builder (October 1898) XI(10):169.

Fripp, Robert Mackay "Block erected on the corner of Cordova and Hastings Streets for Messrs The BC Land and Investment Agency Vancouver, B.C., Vancouver B.C., R. Mackay. Fripp, F.R.I.B.A., Archt Vancouver B.C." Canadian Architect and Builder (February 1896) IX(2):24-25.

Fripp, Robert Mackay "Book Case \& Writing Table in Smoking Room, made in Rimu, Mottled Kauri, Rewa Rewa \& Mangeo, New Zealand Woods for Cuyler A Halland Esq. Design by R. MacKay Fripp, F.R.I.B.A., Vancouver B.C." Canadian Architect and Builder (April 1895) 
VIII(4):56-57.

[Fripp, Robert Mackay] "British Columbia Letter No.I" Canadian Architect and Builder (May 1894) VII(5):50-51.

[Fripp, Robert Mackay] "British Columbia Letter No. II" Canadian Architect and Builder (July 1899) XII(7):137-138.

[Fripp, Robert Mackay] "British Columbia Letter No. III" Canadian Architect and Builder (March 1900) XIII(3):57-58.

[Fripp, Robert Mackay] "British Columbia Letter No. IV" Canadian Architect and Builder (December 1900) XIII(12):234-236.

[Fripp, Robert Mackay] "British Columbia Letter No. V" Canadian Architect and Builder (August 1901) XIV(8):80.

[Fripp, Robert Mackay] "British Columbia Letter No. VI" Canadian Architect and Builder (April 1901) XIV(4):142-143.

[Fripp, Robert Mackay] "British Columbia Letter No. VII" Canadian Architect and Builder (July 1901) XIV(7):142-175.

Fripp, Robert Mackay "Competitive Design for Government House, Victoria, B.C. - Awarded Second Premium' R. M. Fripp. F.R.I.B.A. Architect" Canadian Architect and Builder (July 1901) XIV(7)_plate following p ii.

Fripp, Robert Mackay "Drawing for Mantel for his Honour Judge Spinks, Vernon, BC. R." Canadian Architect and Builder (March 1894) VII(3), third plate illustrated between pp 42-43.

Fripp, Robert Mackay "Foreman and Workman's House to be Erected on the Coldstream Estate near Vernon, B.C. for His Excellency The Governor General of Canada, R. MacKay. Fripp, F.R.I.B.A., Vancouver" Canadian Architect and Builder (March 1895) VIII(3):88-89.

Fripp, Robert Mackay "Masonic Temple,. R. MacKay. Fripp, F.R.I.B.A., Vancouver B.C." Canadian Architect and Builder (July 1895) VIII(7):8889.

Fripp, Robert Mackay "Old Men's Refuge" Canadian Architect and Builder
(July 1894) VII(11):142f.

Fripp, Robert Mackay "Proposed Business Premises, Vancouver B.C., R. MacKay. Fripp, F.R.I.B.A., Architect" Canadian Architect and Builder (December 1895) VIII(12): 144-145.

Fripp, Robert Mackay "Proposed Cottage at Ellerslie, New Zealand. R.M. Fripp, F.R.I.B.A. and G.S. Goldsborough, Architects" [Illustrations Index lists this as "Cottage at Ellerslie, New South Wales"] Canadian Architect and Builder (January 1899) XII(1).

Fripp, Robert Mackay "Residence erected at Swan Lake, Okanagan B.C. for Judge Spinks, R. Mackay. Fripp, F.R.I.B.A. Architect March 1892 Vancouver B.C." Canadian Architect and Builder (November 1895) VIII(2), last plate illustrated between pp 88-89.

Fripp, Robert Mackay "Residence at Vancouver for Captain R Archibald, R. MacKay. Fripp, F.R.I.B.A., Vancouver" Canadian Architect and Builder (March 1895) VIII(3):42-43.

Fripp, Robert Mackay "Sketch for a Bungalow to be built of timber on a foundation of rubble rock walling. R.M. Fripp. F.R.I.B.A. Architect. August, 1895" Canadian Architect and Builder (May 1900) XIII(5):96-97.

Fripp, Robert Mackay "Sketch of an Anglican Church to seat 220 persons" Canadian Architect and Builder (June 1899) XII(6) third plate between pp 120-121.

Fripp, Robert Mackay "Small Hotel to be erected at the crner of Westminster [later Main] Avenue and Powell Street, Vancouver, BC for Dr S.W. Powell. R Mackay Fripp, F.R.I.B.A., Vancouver, BC" Canadian Architect and Builder (August 1894) VII(8).

Fripp, Robert Mackay "The Influence of the Modern Christian Church Upon the Ecclesiastical Architecture of the Dominion" Canadian Architect and Builder (April 1899) XII(4):79-80.

Fripp, Robert Mackay "Types of Pacific Coast Houses" Construction (January 1911) 4(2):47-61, 39 ills. 
"George Selwyn Goldsbro"' Encyclopaedia of New Zealand. Wellington, 1901-1910, II:316.

Henderson's British Columbia Gazetteer and Directory. Vancouver: Henderson Publishing Co., 1897.

Herman, Morton The Architecture of Victorian Sydney. Sydney: Angus and Robertson, 1964.

Hitchcock, Henry-Rusell "Frank Lloyd Wright and the Academic Tradition of the 1890s" Journal of the Warburg and Courtauld Institutes (January-June 1944) VII:46-63.

Hitchcock, Henry-Rusell In the Nature of Materials 1887-1941: the buildings of Frank Lloyd Wright New York: Duell, Sloan and Pearce, 1942.

Illustrated Catalogue of the Fourth Annual Exhibition of the Auckland Society of Arts 1884. Auckland, 1884. [unpaginated].

Illustrated Catalogue of the Seventh Annual Exhibition of the Auckland Society of Arts 1887 Auckland, 1887. [unpaginated].

Johnston, Patricia J and Chénier, Paul R L Index of/du Canadian Architect and Builder, 1888-1908. SSAC/SEAC, 1987.

Jones, Gerald J. "How Houses May Be Improved" Progress (June 1912):1133-1136.

Kalman, Harold D, A History of Canadian Architecture. Don Mills: Oxford University Press, 1994, 2 vols.

Kalman, Harold, Ronald A Philips and Robin Ward Exploring Vancouver: The Essential Architectural Guide. Vancouver: UBC Press, 1993.

Kluckner, Micheal. M.I. Rogers, 1869-1965 Vancouver: privately printed, 1987.

Knight Cyril R The Selwyn Churches of Auckland Wellington-SydneyLondon: AH \& AW Reed, 1972.

"The Late R Mackay Fripp, F.S.A." Construction Vol. XI No. 1 (January 1918):33.

"Library and Archives Canada," last updated 28 November 2007, www.collectionscanada.ca

Luxton, Donald Building the West: the early architects of British Columbia: Talon Books Vancouver, 2003.

Luxton, Donald "Taming of the West: The Thirty Year Struggle to Regulate the Architectural Profession in British Columbia" Journal of the Society for the Study of Architects in Canada/Journal de la société pour l'etude de l'architecture an Canada (1998) 23(4):108 ff.

Maitland, Leslie Queen Anne Revival Style in Canadian Architecture Ottawa: Parks Canada Publication, 1990.

Mills, Edward G and Sommer, Warren Vancouver Architecture 1886-1914 Ottawa: Parks Canada/Canadian Inventory Historic Buildings of the Canadian Historic Sites and Monuments Board, Manuscript Report Series \#254 [Microfiche].

Mills, Edward "Robert Mackay Fripp" Luxton, Donald ed. Building the West: the early architects of British Columbia Vancouver: Talon Books, 2003:158-163.

Minutes of the Auckland Society of Arts 1882-1883 and the secretaries' working copies of the Annual Exhibition Catalogues, MS 19, Box 1, Books I-IV, Auckland War Memorial Museum Library, Auckland.

Neal, Carolyn Eden Smith, Architect, 1858-1949: A Biography Toronto: The Branch, 1976.

Nute, Kevin Frank Lloyd Wright and Japan: The Role of Traditional Japanese Art and Architecture in the Work of Frank Lloyd Wright. London: Chapman and Hall, 1993.

"Obituary: Mr R. Mackay Fripp" The Contract Record (9 January 1918) 32(2):32.

Parker, C.W. ed. Who's Who and Why Vancouver: International Press, 1912.

Parker, C.W. ed. Who's Who and Why Vancouver: International Press, 1913. 
Parker, C.W. ed. Who's Who and Why Vancouver: International Press, 1914.

Parker, C.W. ed. Who's Who in Western Canada Vancouver: Canadian Press Association, 1911.

Peddle, James "Some Lessons We Can Learn From our American Neighbours" Building [Bungalow Number] (20 December 1912).

"Provincial Home" Vancouver Daily World (30 December 1883):8.

"R. Mackay Fripp" Vancouver Daily World (29 March, 1893):8.

Reynolds, Peter L John Horbury Hunt: radical architect 1838-1904. Sydney: Historic House Trust of New South Wales, 2002.

"Robert MacKay Fripp and Charles Edwin Fripp, Architects" Vancouver Daily World (Saturday, 29 March 1890):8.

"Robert Mackay Fripp" Vancouver Daily World (17 December 1917) s 2, p 1.

"Robert Mackay Fripp" Vancouver Daily World Souvenir Edition. Vancouver, 1891:22.

"Robert Mackay Fripp" Who's Who and Why In Western Canada Toronto: Micromedia, nd; original source Vancouver: International Press, 1911:179.

"Robert Mackay Fripp" Who's Who and Why In Western Canada Toronto: Micromedia, nd; original source Vancouver: International Press, 1913:261.

Royal Institute of British Architects (R.I.B.A.) Nomination Papers F 11:19. fiche 110/G2, RIBA Library, London.

"St Paul's Church (Anglican) 141 Chapel Road, Flat Bush, Auckland" New Zealand Historic Places Trust (NZHPT) Building registration no. 690. https://www.heritage.org.nz/the-list/details/690

Salmond, Jeremy Old New Zealand Houses 1800-1940 Auckland: Reed Methuen, 1986.

Scholefield, EOS British Columbia: From the Earliest Times to the Present
Vancouver: SJ Clarke, 1914, v 3.

Segger, Martin The Buildings of Samuel Maclure: In Search of Appropriate Form Victoria: Sono Nis Press, 1986.

Shaw, Peter New Zealand Architecture Auckland: Hodder and Stoughton, 1991.

Sheppard Collection File, G622g, Library of the School of Architecture and Planning, University of Auckland.

Thompson, Stuart H. "George A. Fripp and Alfred D. Fripp" Walker's Quarterly (1927) 7:25-26.

The Vancouver Buildings Register, City of Vancouver Planning Department, Vancouver.

The Vancouver Heritage Inventory, City of Vancouver Planning Department, Vancouver.

"Vancouver Institute Lectures - 1916-1919" University of British

Columbia Archives

http://www.library.ubc.ca/archives/institute/vaninst1.html

"Victoria Arcade, Auckland" Illustrated Australian News (28 January 1884).

Ward, Robin "Architecture: Growth, heritage and the quality of urban life" The Weekly [Vancouver] (13 July 1996):D7.

Williams Official Directory of British Columbia Vancouver: Precision Micrographic Services; original source published Victoria: R.T. Williams, 1893.

Wise's New Zealand Post Office Directory 1885-1886. Dunedin: H. Wise \& Co., 1886.

Wise's New Zealand Post Office Directory 1898-1899. Dunedin: H. Wise \& Co., 1899.

Wright, Frank Lloyd "In the Cause of Architecture" Architectural Record [March 1908] (also republished in Frank Lloyd Wright: Collected Writings New York: Rizzoli, 1992, v 1.) 